\title{
Pengolahan Makanan Berbasis Potensi Desa sebagai Sumber Ekonomi Kreatif Masyarakat
}

\author{
Mega Tunjung Hapsari*1, Bobby Rachman Santoso ${ }^{2}$ \\ ${ }^{1}$ Program Studi Manajemen Keuangan Syariah, ${ }^{2}$ Program Studi Manajemen Dakwah, IAIN Tulungagung \\ *e-mail: hapsarimega11@gmail.com ${ }^{1}$
}

\begin{abstract}
The abundant natural potential in the southern tip of Blitar Regency, East Java Province is not directly proportional to the ability of village communities to manage so that natural products sold at prices below market standards. A mediocre economy makes the group of mothers who are members of the Empowerment of Family Welfare try to get additional income. This dedication has succeeded in realizing the community empowerment program through training on village-based food processing, that is the avocado fruit, as a source of creative economy for the village community. Community service activities are carried out using the ABCD (Asset Based Community Development) method through four steps, namely: 1) Observation; 2) Planning; 3) Implementation; and 4) Evaluation. The results of the community service activities are the creative idea of food processing and aspects of food production. Now village communities, especially housewive, are more creative and empowered and can generate additional income to help the family economy.
\end{abstract}

Keywords: Village Potential, Aset Based Commuity Development, Creative Economy, Food Processing

\begin{abstract}
Abstrak
Potensi alam yang cukup melimpah di ujung selatan Kabupaten Blitar Propinsi Jawa Timur tidak berbanding lurus dengan kemampuan masyarakat desa untuk mengelola sehingga membuat hasil alam dijual dengan harga dibawah standar pasar. Perekonomian yang pas-pasan membuat kelompok ibu-ibu yang tergabung dalam Pemberdayaan Kesejahteraan Keluarga berupaya untuk mendapatkan penghasilan tambahan. Pengabdian ini berhasil merealisasikan program pemberdayaan masyarakat melalui pelatihan pengolahan makanan berbasis potensi desa yaitu buah alpukat menjadi sumber ekonomi kreatif bagi masyarakat desa. Kegiatan pengabdian dilaksanakan dengan metode ABCD (Aset Based Commuity Development) melalui 4 tahapan yaitu: 1) Observasi; 2) Perencanaan; 3) Pelaksanaan; dan 4) Evaluasi. Hasil kegiatan pengabdian adalah ide kreatif pengolahan makanan dan aspek produksi makanan. Kini masyarakat desa khususnya ibu rumah tangga menjadi lebih kreatif dan berdaya serta dapat menghasilkan pemasukan tambahan untuk membantu perekonomian keluarga.
\end{abstract}

Kata kunci: Potensi Desa, Aset Based Commuity Development, Ekonomi Kreatif, Pengolahan Makanan

\section{PENDAHULUAN}

Ekonomi Kreatif merupakan salah satu sektor yang diharapkan mampu menjadi kekuatan baru ekonomi Nasional di masa mendatang. Pemerintah Indonesia berusaha menaruh perhatian lebih terhadap sektor ini, dengan tujuan untuk memaksimalkan potensi dan peluang Ekonomi Kreatif di Indonesia. Berdasarkan data dari Badan Ekonomi Kreatif Indonesia, pertumbuham ekonomi kreatif terhadap Produk Domestik Bruto (PDB) dari tahun 2016-2019 dan tren pertumbuhan tenaga kerja ekonomi kreatif Indonesia tahun 2014-2017 adalah sebagai berikut:

Tabel 1.1 Pertumbuhan Ekonomi Kreatif di Indonesia

\section{PERTUMBUHAN KONTRIBUSI EKRAF} TERHADAP PDB INDONESIA:

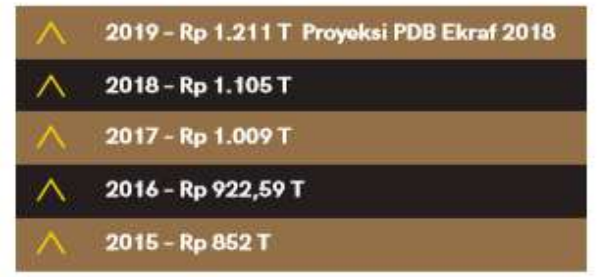

TREN PERTUMBUHAN TENAGA KERJA EKRAF INDONESIA DALAM 4 TAHUN TERAKHIR

\begin{tabular}{lcc}
\hline TAHUN & JUMLAH (DALAM JUTA ORANG) & PERTUMBUHAN (\%) \\
\hline $2017-17,43$ & $4,13 \%$ \\
$2016-16,91$ & $5,95 \%$ \\
$2015-16,06$ & $5,22 \%$ \\
$2014-15,46$ & $2,94 \%$ \\
\hline
\end{tabular}

Sumber: Opus Creative Economi Outlook 2019. 
Data tersebut memberikan informasi bahwa ekonomi kreatif di Indonesia memiliki potensi yang sangat menjanjikan. Seiring dengan hal tersebut, pernyataan Menteri Pariwisata dan Ekonomi Kreatif yang dikutip dari www.bisnis.tempo.co (Nopember, 2019) menyatakan bahwa pengembangan ekonomi kreatif di Indonesia salah satunya yaitu membawa ekonomi kreatif hingga ke pedesaan. Berdasarkan hal tersebut, pengabdian ini berfokus pada upaya peningkatan ekonomi kreatif masyarakat desa.

Lokasi pelaksanaan pengabdian kepada masyarakat berada di Desa Bululawang, Kecamatan Bakung, Kabupaten Blitar. Kondisi ekonomi di Desa Bululawang, Kecamatan Bakung, Kabupaten Blitar, dalam hal pendapatan mayoritas bergantung pada sektor pertanian dan perkebunan. Hal ini dikarenakan oleh profesi warga Desa Bululawang kurang lebih sebesar 65\% berprofesi sebagai petani, sebesar $30 \%$ berprofesi sebagai tenaga kerja di luar negeri, dan sebesar $5 \%$ berprofesi sebagai pedagang.

Salah satu potensi terbesar Desa Bululawang adalah pohon buah alpukat. Berdasarkan hasil observasi yang dilakukan mulai bulan Januari - Februari tahun 2020, tidak sulit untuk mencari buah alpukat di Desa Bululawang, bahkan disetiap sudut mata memandang selalu ada buah alpukat. Hampir di setiap rumah penduduk memiliki pohon alpukat. Namun potensi buah alpukat tersebut belum dimanfaatkan untuk diolah menjadi sesuatu yang memiliki nilai lebih. Berdasarkan hasil observasi tersebut, pengabdian ini menekankan pemberdayaan melalui metode ABCD (Aset Based Commuity Development) yang hasilnya adalah kemampuan menyelesaikan permasalahan dan memberikan manfaat secara praktis dan ekonomis bagi masyarakat Desa Bululawang.

Menurut hasil wawancara dengan Ibu Ketua PKK Desa Bululawang, ditemukan fakta bahwa masih banyak masyarakat belum mempunyai kesadaran untuk memanfaatkan kreatifitas untuk mengolah buah alpukat. Rata-rata hasil panen buah alpukat langsung dijual kepada pembeli atau tengkulak. Berdasarkan analisis situasi tersebut, pengabdian ini dapat menjadi solusi nyata bagi masyarakat Desa Bululawang untuk meningkatkan perekonomian melalui pelatihan pengolahan makanan berbasis potensi desa sebagai sumber ekonomi kreatif masyarakat.

Berdasarkan latar belakang diatas, adapun perumusan masalah yang digunakan pada pengabdian ini adalah "Bagaimana Proses Pengolahan Makanan Berbasis Potensi Desa sebagai Sumber Ekonomi Kreatif Masyarakat?" Sedangkan tujuan dari pengabdian ini adalah:

1) Meningkatkan keberdayaan masyarakat Desa Bululawang dalam pengelolaan potensi alam untuk meningkatkan ekonomi desa.

2) Mendorong ide kreatifitas masyarakat dalam program pelatihan pengolahan makanan berbasis potensi desa sebagai sumber ekonomi kreatif masyarakat.

3) Pada akhirnya, masyarakat menjadi berdaya dan berdikari dalam menyelesaikan permasalahan perekonomian keluarga dan desa dengan kemampuan menciptakan nilai tambah yang berasal dari pengolahan hasil potensi desa.

\section{METODE}

Pengabdian ini menggunakan pespektif pemberdayaan dengan metode ABCD (Aset Based Commuity Development) guna meningkatkan nilai aset yang dimiliki masyarakat untuk memenuhi kebutuhan bagi masyarakat seperti potensi buah alpukat di Desa Bululawang. Hasil pengabdian masyarakat Sukanda (2016); Djawahir (2018) serta Mahmudah dan Supiah (2018), memberikan kesimpulan bahwa penekanan metode ABCD dapat digunakan untuk memprakarsai dan meningkatkan partisipasi masyarakat untuk menolong diri sendiri keluar dari masalah yang ada. Program yang dilaksanakan dalam pemberdayaan ini melalui program pelatihan pengolahan makanan berbasis potensi desa sebagai sumber ekonomi kreatif masyarakat. Aset utama dalam upaya pemberdayaan ini adalah ibu-ibu PKK dan ibu-ibu rumah tangga. Secara rinci kerangka pemecahan masalah pada pengabdian ini adalah sebagai berikut: 


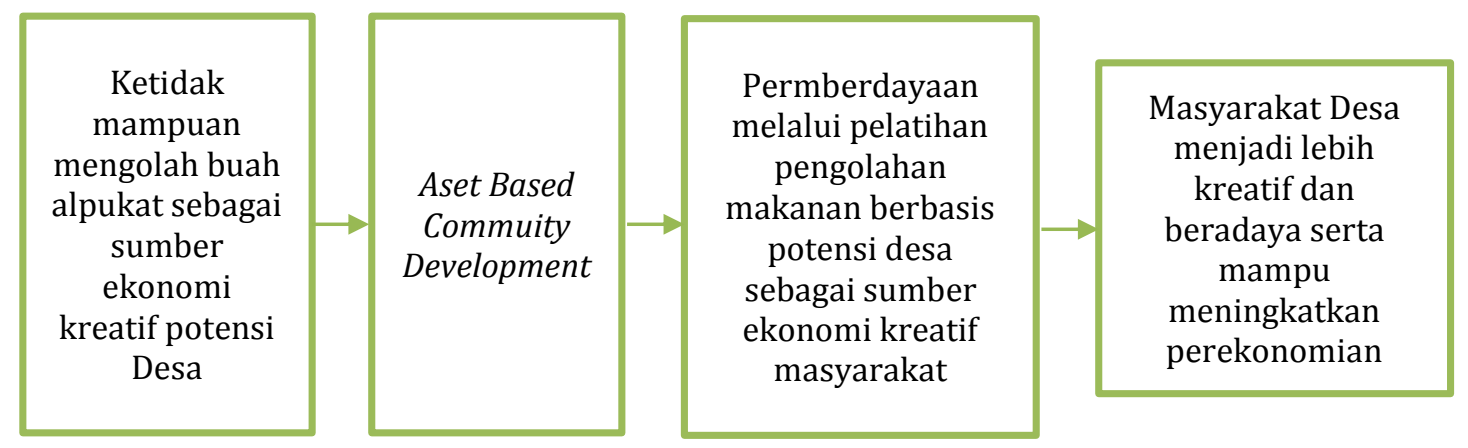

Gambar 2.1 Kerangka Pemecahan Masalah

(Sumber: Olahan Peneliti, 2020)

Tahapan-tahapan dalam metode pengabdian ini adalah sebagai berikut:

1) Observasi

Observasi dilakukan sebelum melakukan pemetaan wilayah untuk mengetahui gambaran awal wilayah yang akan digunakan sebagai sasaran kegiatan pengabdian. Observasi lapangan dilaksanakan dalam waktu satu minggu dengan output berupa gambaran lokasi, kondisi masyarakat, dan potensi yang ada di Desa Bululawang.

2) Perencanaan Program Pengabdian

Langkah perencanaan dilakukan dengan membuat peta transek yang memuat informasi persebaran penduduk berdasarkan profesi dan potensi buah alpukat di desa Bululawang. Kemudian, hasil perencanaan ditindaklanjuti dengan menyusun program pengabdian dan dikonsultasikan dengan Perangkat Desa dan Ketua PKK. Hasil yang telah dikonfirmasi dirinci dalam langkah yang diusulkan sebagai program pelatihan pengolahan makanan berbasis potensi desa sebagai sumber ekonomi kreatif masyarakat.

3) Pelaksanaan Program Pengabdian

Pelaksanaan program dilakukan dengan mendatangkan narasumber yang berkompeten dalam bidang ekonomi kreatif dan produksi makanan. Pada tahap pelaksanaan ini dapat menjadi solusi atas permasalahan muncul di desa Bululawang sesuai hasil observasi dan perencanaan.

4) Evaluasi Program Pengabdian

Tahap ini untuk mengevaluasi pelaksanaan program pengabdian dan menghimpun masukan yang berasal dari masyarakat, perangkat desa, dan akademisi.

\section{HASIL DAN PEMBAHASAN}

Realisasi pengabdian dibahas dalam 4 tahapan sebagai berikut:

1) Observasi

Pengabdi menggunakan observasi partisipasi pada kegiatan pengabdian ini. Menurut Hasanah (2016), observasi partisipasi memungkinkan pengabdi mengetahui betul bagaimana fokus dan lokus kegiatan pengabdian sebab terjun langsung ke lapangan dan berinteraksi dengan masyarakat. Hasil pengebadian Ningsih, Kintoko, dan Puji (2017) juga menggunakan observasi pada perencanaan kegiatan pengabdiannya. Observasi pasrtisipasi dilakukan untuk mengetahui gambaran awal wilayah yang akan digunakan sebagai sasaran kegiatan pengabdian. Observasi lapangan dilaksanakan dalam waktu satu 
minggu pada awal pelaksanaannya. Output observasi berupa gambaran lokasi, kondisi masyarakat, dan potensi yang ada di Desa Bululawang.

Gambaran lokasi Desa Bululawang berada di Kecamatan Bakung, Kabupaten Blitar, Provinsi Jawa Timur. Secara georafis, di sebelah utara Desa Buluwang berbatasan dengan Desa Kedungbanteng, sebelah barat berbatasan dengan Desa Bakung, sebelah timur berbatasan dengan Desa Sidomulyo, dan di sebelah selatan berbatasan langsung dengan samudra Indonesia. Dan Desa Bululawang merupakan desa yang kaya hasil alam berupa buah Kelapa dan buah Alpukat.

Berdasarkan hasil observasi didapatkan data jumlah penduduk Desa Bululawang terdiri dari 446 Kartu Keluarga, dengan jumlah total 1.113 jiwa, dengan rincian 563 lakilaki dan 550 perempuan. Jenis mata pencaharian warga masyarakat Desa Bululawang teridentifikasi ke dalam beberapa sektor, yaitu: pertanian, jasa/perdagangan, industri dan lain-lain. Berdasarkan data yang ada, masyarakat yang bekerja di sektor pertanian sebesar $62,35 \%$ yaitu sejumlah 694 orang, yang bekerja disektor jasa sebesar 8,62\% yaitu sejumlah 96 orang, yang bekerja di sektor industri sebesar 1,3\% yaitu sejumlah 15 orang, dan bekerja di sektor lain-lain sebesar $0,72 \%$ yaitu sejumlah 8 orang. Dengan demikian jumlah penduduk yang memiliki mata pencaharian sehari-hari sebesar $73 \%$, sementara $27 \%$ penduduk tidak memiliki mata pencaharian. Pendapatan dari hasil mata pencaharian penduduk mayoritas adalah upah musiman pada saat panen, dan upah harian yang seringkali kurang mencukupi kebutuhan hidup.

2) Perencanaan

Hasil observasi yang dilakukan menjadi bahan pertimbangan untuk melakukan penyusunan program pengabdian. Langkah perencanaan dilakukan dengan membuat peta transek yang memuat informasi persebaran penduduk berdasarkan profesi dan potensi buah alpukat yang dimiliki. Teknik peta transek merupakan teknik pengamatan langsung terhadap kondisi sumberdaya alam dan lingkungan serta sumberdaya sosial, dengancara menelusuri wilayah desa melalui suatu lintasan tertentu yang telah disepakati bersama. Dalam teknik peta transek ini, masyarakat dilibatkan secara langsung dalam proses pembelajaran untuk mengetahui potensi sumber daya alam dan sumber daya manusia yang ada di wilayahnya (CWMBC, 2013:6).

Berdasarkan hasil peta transek, temuan permasalahan yang dialami masyarakat desa Bulalawang adalah sebagai berikut:

a. Banyak penduduk rentan miskin yang hidup pas-pas an.

b. Banyak rumah tangga yang belum berdaya dan menggantungkan ekonomi keluarga kepada suami.

c. Hampir setiap rumah memiliki pohon buah alpukat yang hasilnya cukup melimpah namun kesulitan mencari pembeli buah alpukat dengan harga sesuai.

d. Hasil panen buah alpukat dijual mentah kepada tengkulak dan pembeli dengan harga dibawah harga pasar.

e. Tidak memiliki keahlian dalam hal produksi dan pengolahan makanan.

Permasalahan-permasalahan di atas perlu diatasi agar masyarakat dapat berdaya dan berkecukupan secara ekonomi dengan hasil potensi desa yang dimiliki. Hasil penelitian Kusumastuti (2017) dan Ruchkina et, al (2017) sepakat bahwa mengembangkan ekonomi dan inovasi melalui usaha kecil menengah dalam masyarakat merupakan salah satu upaya penting yang dapat dilakukan untuk meningkatkan kesejahteraan masyarakat. Berdasarkan permasalahan yang ditemui di atas maka solusi yang ditawarkan pengabdi kepada desa Bululawang adalah melaksanakan program pelatihan pengolahan makanan berbasis potensi desa sebagai sumber ekonomi kreatif 
masyarakat. Proses perencanaan ditindaklanjuti kemudian dikonsultasikan dengan Ibu Kepala Desa selaku ketua PKK. Hasilnya rencana program disetujui dan dikonfirmasi dalam pelaksanaan program pengabdian.

3) Pelaksanaan

a. Waktu dan Tempat

Kegiatan pelatihan dilaksanakan pada hari bulan Februari Tahun 2020 bertempat di Balai Desa Bululawang, Kecamatan Bakung, Kabupaten Blitar. Dalam pelatihan, narasumber menjelaskan tahap-tahap pengolahan buah alpukat menjadi menu kudapan nikmat yaitu kreasi es krim. Dengan dibantu oleh masyarakat dan perangkat Desa, tempat pelatihan berada di Balai Desa Bululawang dengan menyediakan meja dan peralatan memasak yang dapat digunakan masyarakat untuk praktik langsung dalam pembuatan kudapan tersebut. Masyarakat begitu antusias dan aktif berpartisipasi dalam pelatihan.
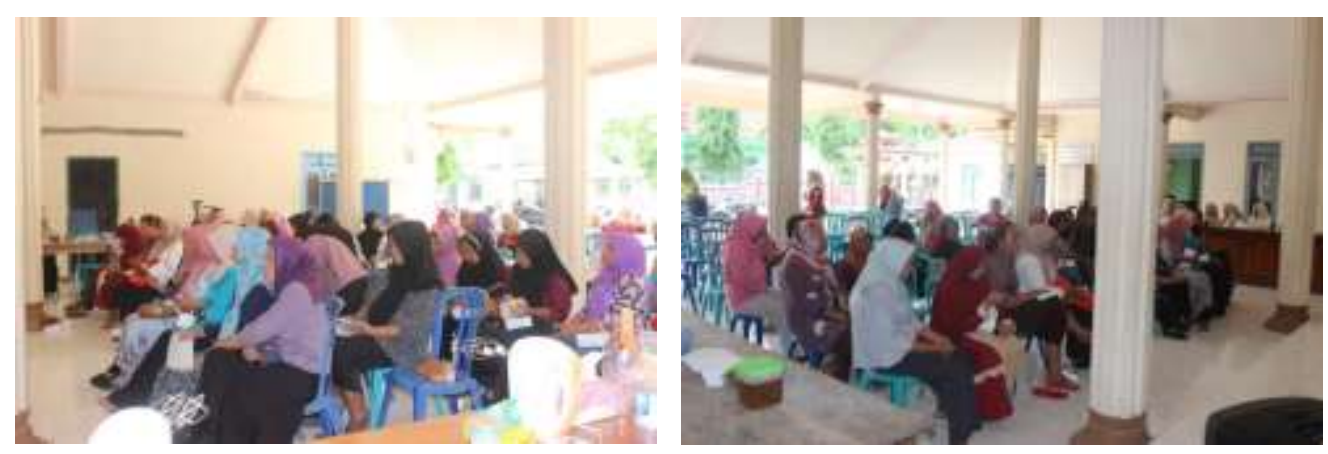

Gambar 3.1 Balai Desa Bululawang sebagai Lokasi Program Pengabdian

b. Pemaparan Cara Pengolahan Makanan

Setelah pembukaan acara oleh Kepala Desa dan Ketua Panitia, narasumber memberikan pemaparan tahap-tahap pengolahan makanan. Adapun tahapan dalam pembuatan es krim alpukat adalah sebagai berikut:

a) Menyiapkan bahan makanan antara lain: tepung maizena, pengembang, santan, susu kental manis, garam, gula, dan buah alpukat.

b) Menyiapkan alat memasak antara lain: kompor, blender/mixer, mangkok besar, mangkok kecil, gelas air, dan sendok.

c) Rebus santan dan tepung maizena tambahkan $300 \mathrm{ml}$ air, beri gula dan garam secukupnya.

d) Setelah direbus sampai mendidih, angkat, kemudian diamkan selamat 15 menit.

e) Blender atau mixer hasil rebusan santan dan tepung maizena sampai lembut, lalu masukan ke dalam wadah dan diamkan di freezer selama 4 jam.

f) Setelah membeku, ambil adonan dan masukan ke dalam blender / mixer, tambahkan 2 buah alpukat yang telah dikupas dan susu kental manis. Blender / mixer sampai lembut.

g) Hasil adonan alpukat siap dikemas dalam wadah ice cream, tambahkan topping sesuai selera, dan masukan kulkas sampai membeku.

h) Kreasi es krim alpukat siap disajikan. 
Adapun resep makanan ini dibagikan kepada masyarakat dalam bentuk leaflet agar mudah dipahami dan dapat dibawa pulang untuk dipraktekan di rumah.
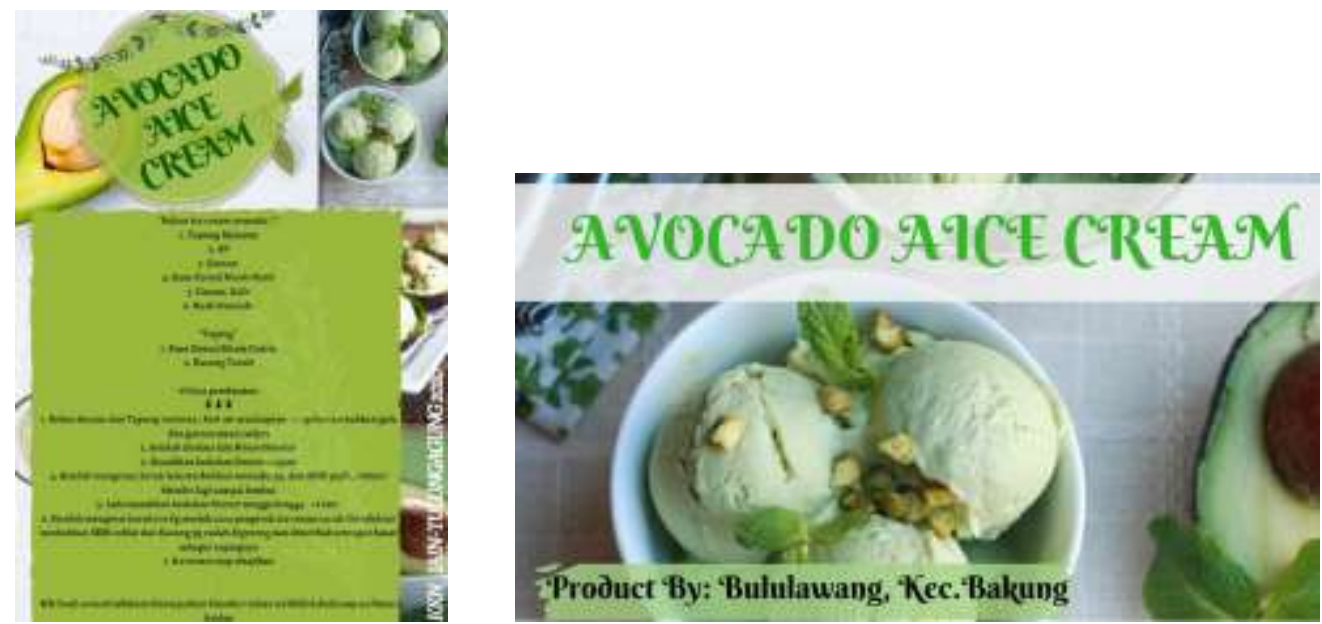

Gambar 3.2 Resep Kreasi Buah Alpukat

c. Praktek Pengolahan Makanan Berbahan Dasar Alpukat

Dalam pelatihan ini tidak hanya praktik mengolah buah alpukat menjadi kreasi es krim, namun juga juga diajarkan tata cara pengemasan dan desain brand produk yang hasil sepenuhnya diberikan kepada ibu-ibu masyarakat Desa Bululawang. Narasumber menjelaskan setiap tahap pembuatan kreasi es krim dibantu oleh panitia yang menjadi tutor disetiap tahap proses pembuatan. Seluruh peserta dapat ikut langsung mempratikan proses pengolahan buah alpukat menjadi es krim. Setiap tahapan pembuatan kreasi es krim alpukat berjalan dengan penuh keceriaan, kemudian hasilnya dibagikan kepada seluruh peserta dan undangan. Senyum dan rasa senang seluruh peserta dan undangan menandakan rasa es krim alpukat sesuai dengan lidah masyarakat Bululawang. Hasilnya masyarakat puas dan mau berkreasi dengan olahan buah alpukat sebagai sarana untuk meningkatkan perekonomian.
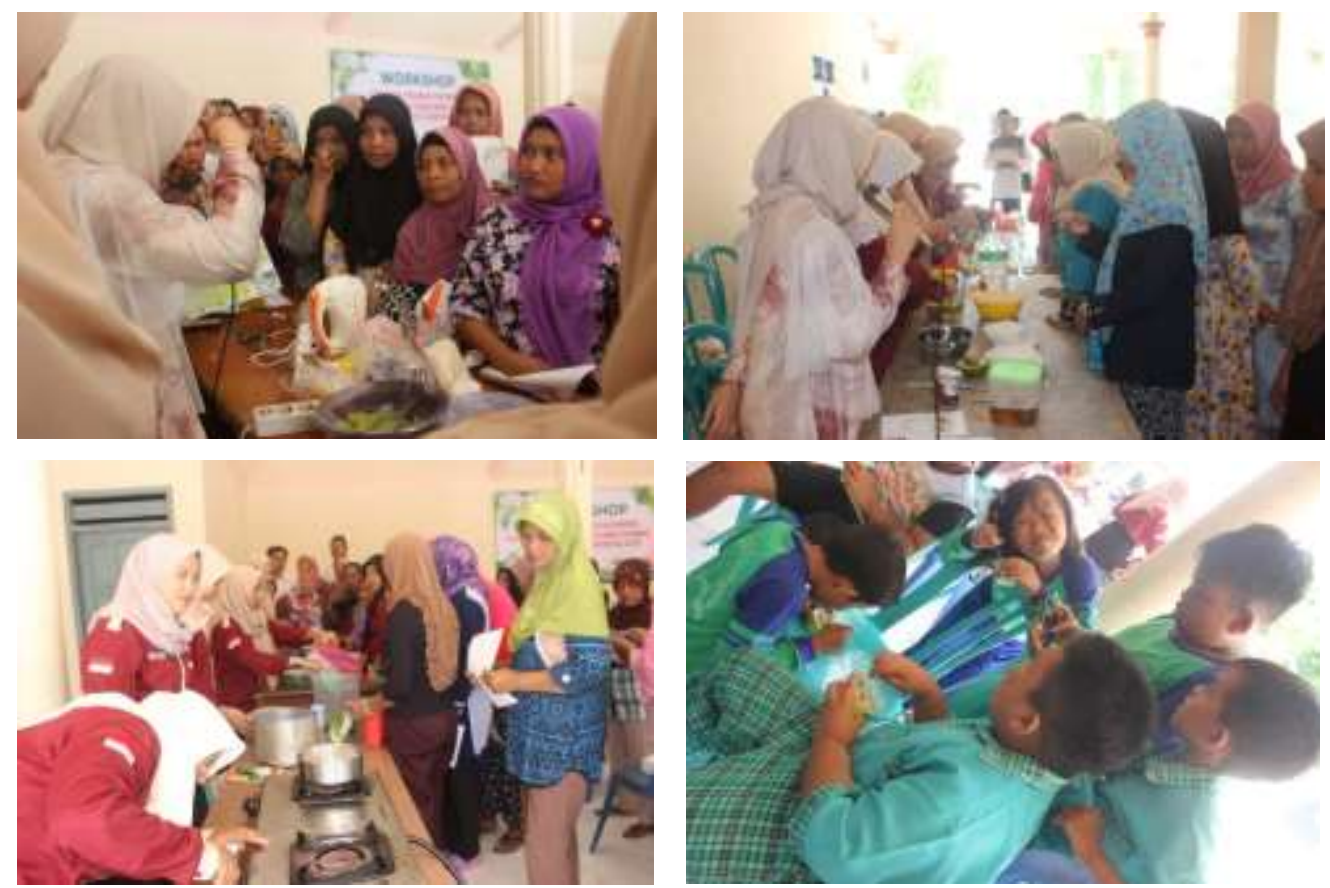

Gambar 3.3 Hasil Kreasi Buah Alpukat menjadi Kudapan Lezat 
4) Evaluasi

Setiap tahapan kegiatan pengabdian telah dilaksanakan sesuai dengan rencana kegiatan. Output dari kegiatan juga telah sesuai dengan rencana. Berdasarkan hasil wawancara yang dilakukan dengan masyarakat yang tergabung dalam kelompok PKK, kegiatan pengabdian ini telah memberikan manfaat yang besar bagi masyarakat. Hal ini terbukti dengan adanya permintaan pesanan es krim untuk acara-acara seperti hajatan, rapat, ulang tahun, dan lain-lain. Disamping itu, hasil kreasi es krim desa Bululawang ini akan diikutkan dalam pameran yang akan diselenggarakan oleh Pemerintah Daerah sebagai upaya promosi desa.

Walapun secara keseluruhan pengabdian ini telah berhasil, ada beberapa hal yang menjadi faktor pendorong dan penghambat pelaksanaan kegiatan pengabdian. Adapun faktor pendukung kegiatan pengabdian, yaitu sebagai berikut:

a. Melimpahnya kebutuhan bahan baku berupa buah alpukat, hamper disetiap rumah penduduk memiliki pohon buah alpukat.

b. Dukungan penuh dari Kepala Desa, Perangkat Desa, dan Ibu-Ibu PKK untuk merealisasikan program pelatihan. Tidak hanya mengundang warga masyarakat untuk hadir, namun juga membantu menyiapkan peralatan yang digunakan saat pelatihan.

c. Partisipasi dan kesadaran masyarakat untuk berkreasi cukup tinggi. Meskipun, terkadang masyarakat banyak mengalami kendala dalam penerimaan informasi namun tidak segan untuk bertanya

Sedangkan faktor penghambat kegiatan pengabdian, yaitu sebagai berikut:

a. Kondisi geografis dan infrastruktur yang kurang memadai. Desa Bululawang terletak di pesisir pantai sehingga kondisi jalan yang dilalui terjal dan berkelok bahkan dibeberapa jalan jika terguyur hujan tidak dapat dilalui sebab sangat membahayakan bagi pengguna jalan. Disamping itu jaringan komunikasi juga cukup sulit sehingga tidak mudah dalam koordinasi dengan pihak Desa untuk menyiapkan program pelatihan.

\section{KESIMPULAN}

Program pelatihan pengolahan makanan berbasis potensi desa sebagai sumber ekonomi kreatif masyarakat menjadi kebutuhan masyarakat khususnya ibu-ibu Desa Bululawang untuk meningkatkan perekonomian. Kegiatan ini juga menjadi solusi terhadap ketidakmampuan masyarakat dalam mengolah potensi desa yaitu buah alpukat sehingga memiliki nilai ekonomi yang lebih tinggi. Disisi lain, pelatihan ini berhasil menumbuhkan kesadaran masyarakat untuk mampu berkreasi dalam mengolah potensi desa yaitu buah alpukat sebagai salah satu sumber ekonomi kreatif. Hasil pelatihan ini adalah masyarakat menjadi mampu mengolah buah alpukat menjadi kudapan lezat yaitu kreasi es krim alpukat. Pengemasan dan brand pronduk yang dihasilkan dapat digunakan untuk mempermudah promosi penjualan. Kini masyarakat Desa Bululawang lebih berdaya dan dapat menghasilkan nilai ekonomi lebih daripada menjual buah alpukat kepada tengkulak yang harganya jauh dibawah harga pasar. Masyarakat puas dengan program pelatihan dan mau berkreasi dengan olahan buah alpukat sebagai sarana untuk meningkatkan Perekonomian Desa.

\section{UCAPAN TERIMA KASIH}

Penulis mengucapkan terima kasih kepada kepada IAIN Tulungagung melalui Lembaga Penelitian dan Pengabdian Kepada Masyarakat yang telah memberikan dukungan dan bimbingan kepada tim pengabdi. Penulis juga berterimakasih kepada Kepala Desa, Perangkat Desa, Ketua 
PKK, dan masyarakat desa Bululawang yang telah mendukung dan berpartisipasi dalam keberhasilan pengabdian ini. Ucapan terima kasih juga kepada semua pihak yang telah membantu memberikan kelancaran pada kegiatan pengabdian ini.

\section{DAFTAR PUSTAKA}

Badan Ekonomi Kreatif. (2019). Opus Creative Economi Outlook 2019. Jakarta: Badan Ekonomi Kreatif.

CWMBC. (2013). Modul Pembelajaran Masyarakat. Bandung: CWMBC.

Djawahir, Abdillah Ubaidi. (2018). Asset Based Community Development di Pesantren Wisata: Implementasi Strategis di PP. An-Nur 2 Al Murtadlo Malang. Jurnal Pengabdian Kepada Masyarakat, 1(1), 23-34.

Hasanah, Hasyim. (2016). Teknik-Teknik Observasi (Sebuah Alternatif Metode Pengumpulan Data Kualitatif Ilmu-ilmu Sosial). Jurnal at-Taqaddum, 8(1), 21-46.

Kusumastuti, Retno. (2017). Innovation Diagnostic of Micro, Small and Medium Enterprises (SME): A comparative study of innovation process of SMEs in Depok and Solo. International Journal of Applied Business and Economic Research, 15(20), 597-605.

Mahmudah, Nurul dan Supiah. (2018). Pemberdayaan Pada Anak-Anak Gang Dolly di SMA Artantika Surabaya dengan Metode Asset Based Community Development. Jurnal Madani, 1(1), 17-19.

Ningsih, S.C; Kintoko; dan Puji H.P. (2020). Inovasi Kemasan dan Perluasan Pemasaran Usaha Rempeyek di Yogyakarta. DINAMISIA: Jurnal Pengabdian Kepada Masyarakat, 4(1), 6-17.

Ruchkina, et al. (2017). Small and Medium Enterprises in the Context of Regional Development and Innovations. Journal of International Studies, 10(4), 259-271.

Sukanda, Rosyikin. (2016). Pemanfaatan Asset Based Community Development Bagi Disabilitas. Jurnal Ilmiah Pekerja Sosial, 15(1), 37-44.

Tempo. (2019). Wishnutama Berambisi Desa Bisa Nikmati Ekonomi Kreatif, 07 November 2019. Diakses dari https://bisnis.tempo.co/read/1269389/wishnutama-berambisi-desa-bisanikmati-ekonomi-kreatif 